\title{
The strategic intersection of HR and CSR: CSR motive and millennial joining intention
}

\author{
Juliet E. Ikhide ${ }^{1}$ (D), Ahmet Tarik $\operatorname{Timur}^{1}$ (D) and Oluwatobi A. Ogunmokun ${ }^{1,2}$ (if \\ ${ }^{1}$ Faculty of Business and Economics, Eastern Mediterranean University, P.O. Box 95, Gazimağusa, North Cyprus, Mersin 10, \\ Turkey and ${ }^{2}$ Rabat Business School, International University of Rabat, Rabat, Morocco \\ Author for correspondence: Juliet E. Ikhide, E-mail: juliet.ikhide@emu.edu.tr
}

(Received 3 April 2021; revised 30 July 2021; accepted 26 August 2021)

\begin{abstract}
The success and competitiveness of an organization recruiting the emerging workforce i.e., millennials can be ascribed in part to the organization's corporate social responsibility (CSR) engagement. This study explores the impact of organizational CSR on Nigerian millennials' joining intention through CSR motive perceptions: CSR-based organizational attractiveness (CSR-based OA) and perceived altruism (PA). To examine the empirical relationship among variables, data were obtained from respondents who were seeking employment or in-between jobs. Results revealed that CSR-based OA and PA significantly mediate the relationship between CSR and millennial joining intention. Findings present a unique perspective that significantly expands the literature. The implications of results are discussed and recommendations to managers are presented.
\end{abstract}

Key words: CSR; CSR-based organizational attractiveness; joining intention; millennial; perceived altruism

\section{Introduction}

The complex, competitive, and ever-changing operational conditions and stakeholder expectations that characterize the business environment, have motivated organizations to utilize corporate social responsibility (CSR) as a strategic instrument that signals them as a preferred employer among potential employees. This underlines the relationship between CSR and human resource management (HRM) (Turner, McIntosh, Reid, \& Buckley, 2019), where an organization's CSR practice can influence its HRM practices as it competes for the latest generation entering the workforce, i.e., millennials. The millennials, who are also referred to as 'Generation Y,' are a generational cohort born into the same socio-cultural and historical context approximately between the mid-1970s to early 2000s (Nolan, 2015; Waples \& Brachle, 2020). Although the birth year boundary of each generational cohort including that of millennials is debatable, they are shaped by the particular period and they develop shared attributes and value systems, which set them apart from other generations (Rank \& Contreras, 2021).

Millennials' values, attitudes, and expectations have been shaped by factors such as increased environmental awareness and impact, television talk shows, social media, and technological developments that were dominant in their formative years (Onukwuba, 2020). They are highly motivated by and sensitive to social issues (Waples \& Brachle, 2020); largely politically and environmentally conscious, have unlimited access to information (Ahmad, 2019) and they pursue outcomes that guarantee their maximum profit (Alonso-Almeida \& Llach, 2019). At the workplace they possess distinct attributes, perceptions, and expectations from their employers and are anticipated to influence and revolutionize the workplace with their unique work attitude 
and expectations (Waples \& Brachle, 2020). Interest has increased among researchers and practitioners concerning how to attract and manage this generational cohort. According to Rank and Contreras (2021), millennials are the largest generational group entering the workforce in massive numbers, gradually replacing older generations at work, and are forecasted to make up to $75 \%$ of the worlds' workforce by 2025 .

A unique approach is needed to appeal to potential millennial employees because past traditional HRM practices of talent attraction have been rendered ineffective (Turner et al., 2019), and recruiting quality employees is now critical for the performance and survival of organizations (Klimkiewicz \& Oltra, 2017). Studies have linked organizational CSR engagement to the different attitudinal dispositions of potential employees (Akhouri \& Chaudhary, 2019). Others specifically indicate that CSR is attractive to stakeholders who have deep sensitivity for CSR and ethical issues (Klimkiewicz \& Oltra, 2017). More recently, researchers propose that stakeholders' attitudinal disposition toward an organization is linked to not only CSR engagements, but also the underlying motives behind CSR engagements (Asante, He, Bosompem, Opata, \& Boadi, 2020; Donia, Ronen, Tetrault, \& Bonaccio, 2019).

Stakeholders perceive an organization's CSR motivation as either company-seeking, which aims at enhancing the economic benefits, reputation, performance, or attractiveness of the firm (i.e., CSR-based organizational attractiveness [CSR-based OA]); or public-serving, which is a company's commitment to CSR due to its desire to contribute to society, and without expectation for stakeholder's reciprocity (perceived altruism [PA]) (María \& Perez, 2018). The motivation why organizations engage in socially responsible activities are important (Asante et al., 2020) but stakeholder's cognitive evaluation in terms of causal attribution associated with CSR as well as perception about CSR motivation leads them to evaluate the personal value of CSR engagement and it also shapes subsequent behavioral outcome (María \& Perez, 2018). Although CSR initiatives can be used to create certain outcomes such as job pursuit intention, and send certain signals about an organization's values such as its obligation to particular social endeavors (Rank \& Contreras, 2021), millennials could correspondingly speculate, form perception, and make decisions about organizations' CSR motives.

Since organizations' CSR motive could influence stakeholders' evaluation of, relationship with, and behavioral outcome toward organizations (Akhouri \& Chaudhary, 2019), it would be vital for organizations to take into account millennial's perception of organizational CSR motivation since CSR-related issues are important to this generational cohort. Today's ethically charged and aware environment could benefit from insights about how CSR motive perception, i.e., CSR-based OA and PA affects millennials, who are at present the burgeoning entrants in the workplace, and their intention to seek employment with an organization. The competition for qualified millennial employees among organizations and the cost associated with employee attraction (Waples \& Brachle, 2020) also buttress the relevance of this study. Furthermore, studies about stakeholder's CSR motive perception have largely concentrated on other stakeholders but millennials (Akhouri \& Chaudhary, 2019; Vuković, Miletić, Čurčić, \& Ničić, 2020), and an ambiguous relationship still exists between CSR and millennial joining intention (Waples \& Brachle, 2020).

The perception of a firm's CSR motives and response to CSR initiatives could be tied to stakeholders' surrounding context. Although CSR initiative is a strategic tool that organizations can wield in portraying themselves to the millennials as an employer of choice (Ouyang, Zhang, \& $\mathrm{Hu}, 2020$ ), mixed signals can be received by stakeholders, since contextual differences may affect how organizations' CSR initiatives are perceived and how other CSR-related decisions are affected (Alonso-Almeida \& Llach, 2019). Different contextual factors such as resource availability, social, or economic influences may challenge or enhance CSR motives and stakeholders' perceptions (Stojanović, Mihajlović, Safronova, Kunev, \& Schulte, 2021). Moreover, most CSR-related studies are predominantly conducted in Western contexts and through perspectives that may be inappropriate to explain or fully comprehend the case in developing economies (Ghosh, 2017). Similarly, despite concerns about millennial recruitment, attraction, and particularly regarding CSR profile 
and practices of organizations, research focusing on millennials in emerging economies such as Africa is lacking (Onukwuba, 2020).

The fact that the millennials in Africa make up to $37 \%$ of the global population of millennials (Onukwuba, 2020) underlines the importance of such research in an African country. Nigeria makes an interesting case since the country is not only the most populous, but also the largest economy where CSR is in vogue (Raimi, 2018). The unique perspective of CSR in Nigeria can be gleaned from the idea that organizations through their CSR practices seek to satisfy and attend to the need of stakeholders and local communities. CSR practices of organizations are usually geared toward the enhancement of societal well-being, community development, and provision of social infrastructures such as education scholarships, skill acquisition programs, etc. given the extent of poor infrastructures and government failure (Uduji, Okolo-Obasi, \& Asongu, 2020). In such a context, CSR motive perception varies along the lines of either compliance with the regulatory requirement of social and environmental policies or as voluntary altruistic initiatives (Raimi, 2018).

\section{Purpose and significance of the study}

This research addresses the gap in the literature regarding CSR, CSR motive perception, and behavioral disposition of millennial stakeholder's inadequate research in developing nations such as Nigeria. It aims to explore the impact of CSR on joining intention of millennials in Nigeria through CSR motive perception (CSR-based OA and PA). We examine if millennials as prospective applicants perceive the motive underlying organizations' CSR engagement, and the study seek to understand whether CSR motive perception plays any role in the indirect relationship between CSR and millennial's intention to seek employment with an organization. This is because it has become crucial for organizations to show the sincerity of CSR engagements, to manage inconsistencies regarding organizational CSR motives, and garner favorable millennial joining disposition (Ramasamy, Dara, Amran, \& Nejati, 2020).

This research makes contributions to the literature. First, if CSR, CSR motive perception, and its impact on millennial behavior outcome are considered in a non-Western context, the exploration of the field can be more conclusive and robust since most developing nations are rapidly expanding in terms of economy, lucrative markets, and a young labor force seeking employment. Moreover, such research in a non-Western context could provide valuable data and contribution to meta-analysis studies seeking to determine trends in the research field. It, thus, adds to the earlier studies (e.g., Alonso-Almeida \& Llach, 2019; Klimkiewicz \& Oltra, 2017; Waples \& Brachle, 2020), and extends the knowledge base about CSR and millennials, particularly from the perspective and context of a developing nation. Second, by focusing on the CSR motive perception of potential millennial employees, the present research contributes to the literature because other studies in the literature have majorly focused on other stakeholders' groups; such as employees (Donia et al., 2019), consumers (María \& Perez, 2018), etc. Third, this study expands the literature by revealing the process through which CSR and CSR motive perception influences millennial intention to pursue employees, thus contributing to the literature on recruitment by identifying aspects related to CSR in attracting quality potential employees.

The structure of the paper is as follows: the Introduction is followed by an extensive review of the literature and theoretical support section that focus on this study's variables including CSR, millennial CSR motive perception (CSR-based OA and PA), joining intention and the theories signaling and stakeholders - used in this study. Research hypotheses were developed in the next section. The 'Methodology' section thoroughly discusses the procedure from data collection to hypothesis testing and other empirical analyses, which is followed by the 'Results' section. The findings are discussed in the 'Conclusion and discussion' section. The paper is concluded with implications, limitations, and suggestions for further studies. 


\section{Literature review}

\section{Perceived CSR}

The construct CSR has no doubt attracted a significant level of attention from not only business practitioners or researchers, but also the general public. CSR, which encompasses a firm's ethical obligation toward various stakeholders to perform business operations responsibly, and serve in capacities that exceed their economic interest in the society (Turker, 2009) has recently emerged as a core business practice for several businesses. Turner et al. (2019) argue that CSR has been a standard practice for contemporary organizations. It is now a strategic course companies take to thrive in a highly competitive business environment. Turker (2009) asserts that the structure of CSR practices targets social stakeholders such as customers, employees, non-government organizations, government, the society; and non-social stakeholders such as the unborn generation and the natural environment. Some studies emphasized internal and external stakeholder dimensions of CSR (Rank \& Contreras, 2021). The external CSR dimension, which is the focus of this study, covers the local society and the environment, while employee relations is the focus of the internal dimension.

The different context stakeholders are embedded in promotes the different CSR perceptions they may have (Stojanović et al., 2021), because CSR could be conceptually indistinguishable, or intertwined with other related notions such as corporate citizenship, corporate community involvement, corporate sustainability, stakeholder management, and business ethics (Waples \& Brachle, 2020). In addition, globalization, the increase in social activism, required transparency and expectation of corporate citizenship from firms (Turner et al., 2019), have made information about organizations' CSR activities available to the socially aware and informed public. Stakeholders can evaluate an organization's CSR practices from information readily available in the media or from other direct and indirect interactions with the firm (Ouyang, Zhang, \& Hu, 2020). Such information has been found to either displease, please, or appease stakeholders as well as bear certain benefits.

Regardless of the cost associated with CSR activities, organizations continue to undertake them because of growing expectations from stakeholders and also perceived benefits associated with CSR engagements (Waples \& Brachle, 2020). CSR is held to be a forbearer of long-term profit and socially responsible brand image (Turner et al., 2019). It has also been associated with potential or incumbent employees' satisfaction, engagement, turnover intention, organizational attractiveness, and job pursuit intention (Akhouri \& Chaudhary, 2019). Although existing CSR research has enhanced our understanding of the relationships between CSR and other related outcomes, those that comprehensively interrogate the direct and underlying relationship between CSR and millennial joining intention are inadequate.

\section{Millennials' perception of organizational CSR motive}

Examining stakeholder's perceptions about companies' CSR motives is a recent development in CSR-related research (Donia et al., 2019). In developing nations, organizations in sectors (e.g., oil and gas) with potentially adverse environmental impact are increasingly experiencing controversy around CSR initiatives, stakeholders' perceptions, and actions. Although these firms portray a responsible image by voluntarily and formally disclosing information about their CSR initiatives and their societal impact, CSR practices are still met with mixed perceptions (Nwagbara \& Belal, 2019). Such perception may affect millennials' assessment of the company's CSR motivation as attractive, driven by company-seeking with expected reputational benefit, or as purely altruist (María \& Perez, 2018). This perception can be quite influential when millennials consider employment with a company.

\section{CSR-based organizational attractiveness (CSR-based OA)}

Given the strategic importance of millennial talent as competitive enablers for today's business, attracting and managing this cohort cannot be sidelined by organizations. As organizations in 
the corporate world compete for human resources (Ikhide, Timur, Ogunmokun, \& Bayighomog, 2019), branding has become an important corporate strategy to respond to the challenges firms face in attracting and maintaining human capital (Kumari \& Saini, 2018). Kumari and Saini (2018) assert that employer brand strategy encompasses the practices, tools, and principles by which an organization creates its reputation, brand, or image to specific stakeholders. CSR practice is an observable attribute of an organization's brand that can be controlled by the organization and evaluated by stakeholders (Ronda, Valor, \& Abril, 2018). That is, employer branding strategy based on CSR practice can be used by organizations to create and signal a positive corporate image.

CSR-based organizational branding carries company-seeking motives which are similar to firmserving, strategic-driven (Wongpitch, Minakan, Powpaka, \& Laohavichien, 2016), and extrinsic (Du, Bhattacharya, \& Sen, 2007) CSR motivation. By providing details about CSR practice, morals, and values, organizations are able to influence stakeholders' perceptions (Carlini, Grace, France, \& Lo Iacono, 2019). Although stakeholders holistically assess an organization based on received signals from branding, CSR-based OA is the cognitive impression based on CSR that the target stakeholder, i.e., prospective millennial employees have about an organization as a place of potential employment (Carlini et al., 2019). CSR-based OA is a symbolic employer attribute (Klimkiewicz \& Oltra, 2017) because CSR, similar to other symbolic factors, is the intangible and abstract quality of the company's branding which people can identify with. They also leave an impression on the minds of potential employees because it can help enhance their self-image, maintain a self-identity, express their values, or impress others around them (Kumari \& Saini, 2018).

\section{$P A$ of $C S R$}

The basis for pro-social actions such as philanthropy or CSR practice is altruism (Paraskevaidis \& Andriotis, 2017). Generally described as an unselfish behavior toward others, exalting 'others' welfare above one's own and without an inclination toward reciprocation (Paraskevaidis \& Andriotis, 2017), altruism has been studied because of its relevance to understanding social behaviors. Organizations can be identified as altruist when CSR initiatives are performed with the motive of doing good, fulfilling societal obligation, or engaging in CSR practices that transcend transactional benefits (e.g., reputation enhancement or positive advocacy) for the firm; which earlier research suggest as 'payback for CSR' (Du, Bhattacharya, \& Sen, 2007, p. 225). In the literature, altruistic CSR motivation is closely associated with public-serving, value-driven (Wongpitch et al., 2016), and intrinsic (Du, Bhattacharya, \& Sen, 2007) CSR motivation. Altruist CSR behaviors are devoid of company-seeking interests but full of moral intention and pure motive (Paraskevaidis \& Andriotis, 2017).

It is also emphasized that individual perception of altruistic CSR behavior determines whether such deeds will be met with commendation, indifference, or condemnation (Carlson \& Zaki, 2018). PA refers to stakeholder's evaluation of an organization's motive for CSR as genuinely enhancing the welfare of the society even at the expense of the organization's benefits, and without expected payback (Rim, Yang, \& Lee, 2016). PA has recently been emphasized by scholars in understanding stakeholders' engagement with organizational CSR, since company-seeking motives have not always been met with favorable stakeholder perception but increased CSR skepticism (Rim, Park, \& Song, 2020). Stakeholders' perception of CSR motives as altruism is more likely to lower CSR skepticism (Ramasamy et al., 2020). Other researchers have, on the contrary, argued that however altruistic an organization's CSR behavior may seem, it is in core driven by company interest (Carlson \& Zaki, 2018).

\section{Joining intention}

People maintain perceptions about organizations even before joining them. The intention to pursue employment with an employer portrays the applicant's decision, interest, and willingness to 
apply for an employment position with a particular employer (Highhouse, Lievens, \& Sinar, 2003). It does not only include thoughts that indicate further action about an organization, but also actions such as applying for a vacant position, accepting invitation offers, and accepting a job offer (Highhouse, Lievens, \& Sinar, 2003). The competitive nature of the market, which increased rivalry among companies for scarce human resources, has made it more difficult for companies to attract qualified and suitable talent.

As a result, organizations seek out ways of distinguishing and marketing themselves by engaging in CSR and incorporating CSR-based branding strategies into their overall strategy (Carlini et al., 2019). This has been found to boost the joining intention of potential employees (Kumari \& Saini, 2018; Turner et al., 2019). Klimkiewicz and Oltra (2017) also state that potential employees' intention to pursue employment with an organization depends on the organization's image; with CSR considered as an extension. Although CSR and related CSR-based strategies may not directly result in joining intention; other psychological factors such as CSR-based OA and PA and socioeconomic elements, may be involved in the decision-making process (Chaudhary, 2019).

\section{Theoretical development}

\section{Signaling and stakeholder's theory}

In this study, signaling theory draws on stakeholders' theory, such that stakeholders (potential millennial employees) rely on information signaled by organizations to develop CSR-based perception and make the decisions to join the organization. Although stakeholder's theory describes a stakeholder as a group that can affect and be affected by the realization of an organization's objectives (Freeman, 2010), signaling theory, in turn, suggests that stakeholders search out signals/cues about organizations, interpret the signals and are guided by their perception about those signals when making decisions (Spence, 1978).

The decision-making process is largely affected by the information made available to the deciding parties and signaling theory is useful for interpreting the cues between the sender, i.e., the organization, and the receiver-potential employees (Connelly, Certo, Ireland, \& Reutzel, 2011). According to Connelly et al. (2011), the signaling party makes a concerted effort and decision on how to communicate the intended information, and the party receiving the signal must choose how to decipher the received signal. The signaler uses persuasive and intentional action to communicate both positive signals including CSR practice and information about otherwise imperceptible qualities about the organization (Carlini et al., 2019; Nwagbara \& Belal, 2019). The theory generally proposes that information asymmetry which exists between the signaling organization and potential employees generates some sort of dependence on the sent signal (Connelly et al., 2011), which facilitates the formation of CSR perception by potential employees (Waples \& Brachle, 2020). The theory has been used in the literature to investigate the behavior of job seekers (Ronda, Valor, \& Abril, 2018), and also to explore the relationship between organizational CSR, CSR-based information, motives, and related outcomes such as joining intention of millennials (Akhouri \& Chaudhary, 2019).

Based on the stakeholder theory, organizations disclose information about their CSR engagements to maintain the relationship they have with stakeholders (Freeman, 2010) with whom they have some sort of interdependent relationship (Ogunmokun, Timur, \& Ikhide, 2021b). Since stakeholders are impacted by and can impact an organization's outcome, the organization has to be conscious of the impact and the perception stakeholder have about their activities (Ogunmokun, Timur, \& Ikhide, 2021b), as this could affect millennials' disposition. In other words, prospective employees, as a stakeholder group, can establish certain perceptions about organizations and their CSR practices from signals received from the organization. They can also make decisions through their assessment of the organization's CSR motives off the CSR standing of the firm. This affects their relationship with an organization and is central to the stakeholders' theory perspective. 


\section{Hypothesis development}

\section{Perceived CSR and joining intention}

Attracting quality employees is vital for the survival of any firm, and employers with poor reputations are less likely to attract competent job seekers (Klimkiewicz \& Oltra, 2017). Although this stance is consistent through the recruitment literature, socially responsible organizations are more likely to portray a positive image that would attract millennial talent (Kumari \& Saini, 2018). As the older generation leaves the workforce, organizations are left to hire the millennials; the emerging workforce that seeks meaningful employment with organizations that are involved with the community, have a strong social and environmental agenda as part of their company values, and in general have a socially responsible image (Waples \& Brachle, 2020). The values (e.g., engaging in a cause bigger than themselves and wanting to make a difference) millennials hold can be argued to be the reason for their attraction to socially responsible employers (Alonso-Almeida \& Llach, 2019). In view of this, organizations can use their CSR practices to signal to potential millennial employees and enhance their overall organization image by communicating their CSR information.

Millennials correspondingly evaluate an organization's signal and can consider pursuing employment with them based on their actual CSR practice and communicated CSR information. Since CSR practices are not only desirable to society but also a sensitive issue to millennials, they would want to identify and connect with a socially responsible organization. This is consistent with the finding that CSR is a symbolic attribute that organizations can take on, and stakeholders are happy to identify with an organization that has an image of 'doing good' for the society and larger environment (Lievens \& Slaughter, 2016; Turner et al., 2019). But, what is covered in the literature is a blanket overview of millennials; concerning their general evaluation of an organization, their decision to pursue employment, and to accept or reject an employment offer based on the organization's CSR profile (Klimkiewicz \& Oltra, 2017; Waples \& Brachle, 2020). This deduction was mainly arrived at by examining millennials in societies that are developed and organized. But, other contexts in which millennials are embedded should also be considered (Alonso-Almeida \& Llach, 2019) because this can shed light on the divergences and specifics that can be pertinent for HRM and CSR. We, therefore, propose that:

Hypothesis 1: There is a relationship between perceived CSR of an organization and millennials' intention to join that organization.

\section{PA and CSR-based OA as mediators}

The inconclusive and inadequate state of research concerning CSR and millennial joining intention (Waples \& Brachle, 2020), the associated cost of successfully attracting millennials in a competitive environment, the level of sensitivity millennials have toward CSR and the effect of varying contextual factors that affect both CSR engagement and employment decision (Alonso-Almeida \& Llach, 2019) require examining CSR-related predictor of joining intention and the underlying relationship between CSR and joining intentions. According to Ogunmokun, Timur, Bayighomog, and Ikhide (2021a) stakeholders make causal attributions, which are cognitive processes based on the perception that explain events such as organizational CSR engagements. CSR-based OA and PA of CSR are proposed mediators that could play a major role in gaining in-depth insight into the indirect relationship between perceived CSR and millennial joining intention.

Although a company's CSR initiative displays its commitment to positively impact its society and environment, Rim, Yang, and Lee (2016) posit that the motivation behind CSR is not totally altruistic. Rather, in many circumstances, such CSR initiatives are transactional and have expected reciprocation undertone. Stakeholders are expected to reciprocate with a favorable attitudinal disposition when they perceive that an organization considers socially responsible business 
processes, and acts responsibly in dealing with the environment, society, and stakeholders (Vuković et al., 2020). The same argument can explain why CSR initiatives are always communicated to the public and not kept anonymous (Kotek, Schoenberg, \& Schwand, 2018). Therefore, it could be argued that CSR is not merely a product of sheer altruistic motivation but a part of the organization's business strategy to gain CSR-based OA. On the other hand, a stream of research argues for the possibility of altruistic CSR motives not regarded as a means to CSR-based OA but an end in itself (Paraskevaidis \& Andriotis, 2017).

María and Perez's (2018) CSR cognition-attitude model provides insight into different antecedents and consequences of CSR attitude. According to the model, millennial's CSR cognition (i.e., CSR-based OA and PA), which are formed by interpreting organizations' CSR signals (practice, information, and motive), will often precede attitudinal intention (joining intention). A company may attract favorable attitudinal disposition from stakeholders owing to its engagement in CSR initiatives. The literature further suggests that stakeholders' perception of CSR motive plays a role in how they respond to the organization (Vuković et al., 2020). For instance, only CSR motives perceived as public-serving (akin to PA) resulted in favorable attitudinal disposition such as employee connection and identification with their organization as well as other performance benefits to the organization (Donia et al., 2019). Firm-serving motive (akin to CSR-based $\mathrm{OA}$ ) has been associated with a negative disposition toward firms while public-driven (akin to PA) generates positive CSR-based organizational evaluation and attitudinal disposition including stakeholder engagement (Jiang \& Luo, 2020; Rim, Park, \& Song, 2020).

Although employees may display unfavorable attitudes toward CSR-based OA because motives behind such CSR initiatives are usually perceived as neither sincere nor aimed at improving societal or environmental welfare, it should be noted that potential millennial employees may differ in their perception about CSR motives of an organization. Different stakeholder groups may differ in their perception of organizational CSR motives because of the amount of CSR information they are privy to (Rank \& Contreras, 2021). Contextual factors may be influential in determining their attitudinal response as well (Vuković et al., 2020). The millennials may have a different perception about CSR motives since the wider society always benefits from CSR even those perceived as enhancing the attractiveness (CSR-based OA) of the organization (Kotek, Schoenberg, \& Schwand, 2018). Although a millennial's disposition to go through with the decision of seeking employment with an organization based on their CSR perception (CSR-based OA and PA) may not be a simple psychological process; CSR perception according to María and Perez (2018) precedes attitudinal disposition, i.e., millennial joining intention regardless (Figure 1). In a bid to understand the underlying relationship between CSR and millennial joining intention through CSR-based OA and PA it is hypothesized that:

Hypothesis 2a: The relationship between perceived CSR of an organization and millennial intention to join that organization would be mediated by perceived altruism (PA) of the organization

Hypothesis 2b: The relationship between perceived CSR of an organization and millennial intention to join that organization would be mediated by CSR-based organization attraction (CSR-based OA) of the organization.

\section{Methodology}

\section{Participants}

To empirically validate the proposed hypotheses, millennials who are in-between jobs or seeking employment across Nigeria were approached for data collection. The participants were attendants in job fairs and career seminars organized for employment seekers. A random sampling technique was employed. Potential respondents were invited to participate from different events in different Nigerian cities. Participation in the study was voluntary and all respondents were 


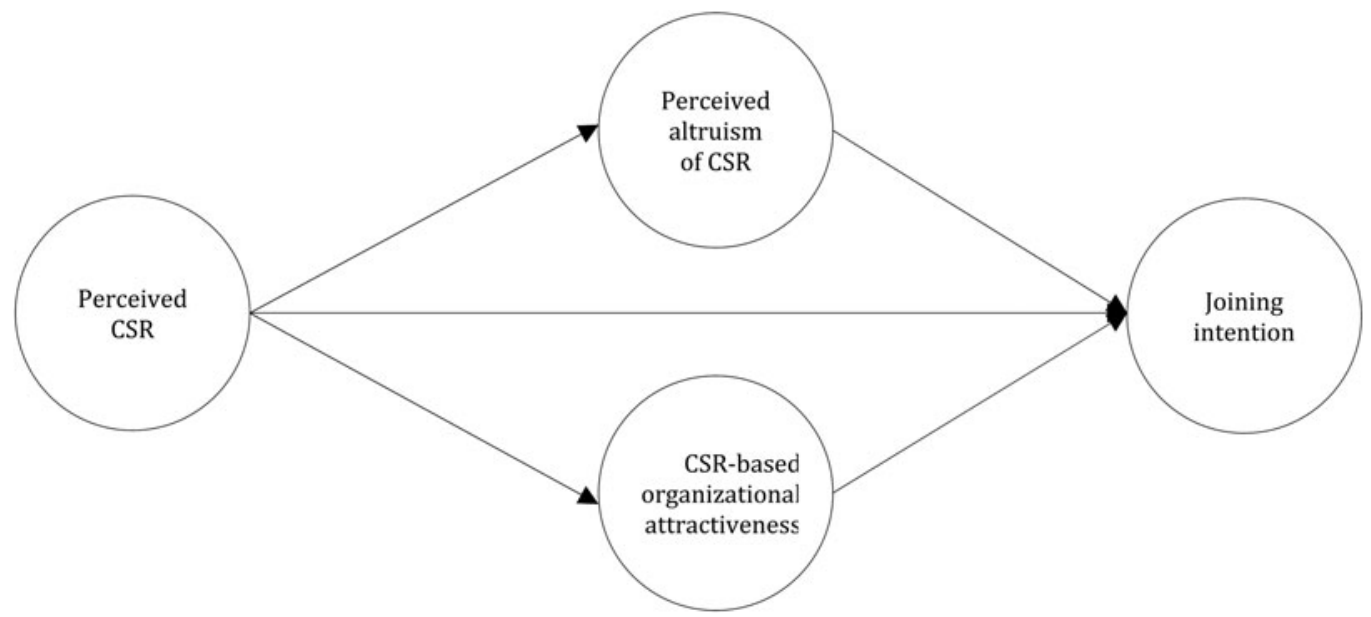

Fig. 1. Conceptual model.

guaranteed anonymity. Our potential respondents were aware of organizational CSR practices through job fairs, online advertisements, company websites, social media, and personal networks.

In the sample, $52.7 \%$ of the respondents were female, $47.3 \%$ male. This could be explained because of the general stereotype, minority status, and role-based standard of the female gender (Nadler, Gann-Bociek, \& Skaggs, 2017); factors that make females less desirable by employers and more likely to be in higher numbers at job fairs and related events. In total, $71.2 \%$ of the respondents were between 18 and 26 years of age, $18.8 \%$ were between 27 and 35 years of age, and $10 \%$ were between 36 and 44 years. This study's age range for millennials is very inclusive and in line with studies in the literature (e.g., Nolan, 2015; Ogunmokun, Eluwole, Ikhide, \& Lasisi, 2020; Waples \& Brachle, 2020). In total, $82.1 \%$ of the respondents had completed an undergraduate degree while the remaining $17.9 \%$ possessed a postgraduate degree. Refer to Table 1.

\section{Procedure}

The distributed questionnaire had three parts: the first part contained a general overview, introduction, and instruction to respondents; the second section was about personal data and demographics while the third contained survey items that were acquired from scales that have been validated by previous studies.

Since our respondents were attendees at 1-day job fairs and career seminars, it was apparent that it may have been difficult and resource-consuming to find the same respondents to fill the questionnaire in two waves. Thus, as an apriori measure to prevent common method bias issues, our survey items were mixed in the questionnaire to provide some temporal and psychological separation in the respondent's mind (Conway \& Lance, 2010). Mixing survey items by not arranging them sequentially by variables impacts the quality of responses received by lessening the potential for response sets, decreases the adverse effect of item order on theoretical testing and mitigates order effects such as respondents having a desired relationship among variables (Podsakoff, MacKenzie, Lee, \& Podsakoff, 2003). This method has been employed in some CSR-related studies (Ogunmokun \& Timur, 2021). Out of the 500 questionnaires distributed at the events, a total of 330 responses were analyzed after incomplete questionnaires were excluded, giving a response rate of $66 \%$. The response rate is moderately high, and this could be because respondents were comfortable in filling out the survey as anonymity was guaranteed, and the length of the survey was relatively short. 
Table 1. Demographics

\begin{tabular}{|lcc}
\hline & Frequency & Percent \\
\hline Gender & & 47.3 \\
\hline Male & 156 & 52.7 \\
\hline Female & 174 & 71.2 \\
\hline Age & & 18.8 \\
\hline $18-26$ & 235 & 10.0 \\
\hline $27-35$ & 62 & 82.1 \\
\hline $36-44$ & 33 & 17.9 \\
\hline Education level & & 271 \\
\hline Bachelor degree & 59 & \\
\hline Master degree & & \\
\hline
\end{tabular}

\section{Measurements}

All items were measured at an individual level on a 5 Likert scale; from strongly agree to strongly disagree because perceptions of CSR motive may vary among prospective applicants just like the perception of other workplace-related variables (Nishii, Lepak, \& Schneider, 2008).

Perceived CSR is measured using Turker's (2009) items. The items measure how participants perceive an organization's external CSR to society, the future generation, the natural environment, and non-governmental organizations $(\alpha=.89)$. Millennial joining intention was measured with items $(\alpha=.80)$ adopted from the studies by Turban and Keon (1993) and Highhouse, Lievens, and Sinar (2003). CSR-based OA was measured with items $(\alpha=.83)$ adapted from Highhouse, Lievens, and Sinar (2003) and Vlachos, Panagopoulos, and Rapp's (2013) study addressing an organization's attractiveness based on CSR motive perception. The root phrase 'based on an organization's CSR profile' was added to the items which measure the extent to which the respondent wants to apply or accept a job offer from a company based on its CSR profile. PA was assessed with items $(\alpha=.84)$ adapted from Rifon, Choi, Trimble, and Li (2004) and Rim, Yang, and Lee (2016) study. It measures respondents' perception of an organization's CSR engagement as purely altruistic or public-serving.

\section{Control variables}

Scholars have demonstrated that certain demographic variables such as gender and education level could have a significant influence on the current study's variables. For example, Tsai and Yang (2010) demonstrated that gender is related to organizational attractiveness. Similarly, Nadler, Gann-Bociek, and Skaggs (2017) demonstrated that gender relates to the perceptions of organizational attractiveness. Furthermore, Warmerdam, Lewis, and Banks (2015) argued that education level could influence millennials' joining intentions. Therefore, to control for the effect of education and gender, they were included as covariates in this study (see Table 3).

\section{Results}

\section{Preliminary analysis}

The data's normality was checked using the SPSS IBM program and the variables' skewness and kurtosis are within acceptable thresholds. Using AMOS 24, the measurement instruments' factorial validity was also carried out. Each construct's internal consistency is acceptable as they all 
Table 2. Factor analysis

\begin{tabular}{|c|c|c|}
\hline Items & Loadings & $\begin{array}{l}\text { Cronbach's } \\
\text { alpha }\end{array}$ \\
\hline Perceived CSR & & .894 \\
\hline $\begin{array}{l}\text { It appears that this company participates in activities that aim to protect and } \\
\text { improve the quality of the natural environment. }\end{array}$ & .949 & \\
\hline $\begin{array}{l}\text { It appears that this company makes investment to create a better life for the } \\
\text { future generations. }\end{array}$ & .937 & \\
\hline $\begin{array}{l}\text { It appears that this company implements special programs to minimize its } \\
\text { negative impact on the natural environment. }\end{array}$ & .921 & \\
\hline $\begin{array}{l}\text { It appears that this company targets a sustainable growth, which considers to } \\
\text { the future generations. }\end{array}$ & .784 & \\
\hline $\begin{array}{l}\text { It appears that this company supports the non-governmental organizations } \\
\text { working in problematic areas. }\end{array}$ & .774 & \\
\hline $\begin{array}{l}\text { It appears that this company contributes to the campaigns and projects that } \\
\text { promote the well-being of the society. }\end{array}$ & .612 & \\
\hline $\begin{array}{l}\text { It appears that this company encourages its employees to participate to the } \\
\text { voluntarily activities. }\end{array}$ & .565 & \\
\hline Perceived altruism & & .847 \\
\hline This organization really wants to help improve society with its CSR programs & .907 & \\
\hline $\begin{array}{l}\text { The motives of this organization in helping the society with its CSR programs } \\
\text { are very pure }\end{array}$ & .897 & \\
\hline This organization does not expect anything in return for its CSR programs & .731 & \\
\hline This organization does not have any hidden agenda for its CSR programs & .639 & \\
\hline Being socially responsible institution is really this organizations mission & .549 & \\
\hline CSR-based organizational attractiveness & & .837 \\
\hline For me, this company would be a good place to work & .778 & \\
\hline I would not be interested in this company, except as a last resort. & .773 & \\
\hline This company is attractive to me as a place for employment because & .770 & \\
\hline I am interested in learning more about this company. & .766 & \\
\hline A job at this company is very appealing to me. & .609 & \\
\hline Joining intention & & .804 \\
\hline I would accept a job offer from this company & .883 & \\
\hline I would make this company one of my first choices as an employer. & .852 & \\
\hline If this company invited me for a job interview, I would go. & .672 & \\
\hline I would exert a great deal of effort to work for this company & .582 & \\
\hline My willingness and likelihood to apply for a job at this firm is high & .534 & \\
\hline
\end{tabular}

Kaiser-Mayer-Olkin (KMO) value $=.771$.

exceed the .7 thresholds (Nunnally, 1978). Convergent validity was also acceptable as all standardized factor loadings were statistically significant and greater than .5 (Hair, Black, Babin, \& Anderson, 2010). Similarly, constructs' average variance extracted (AVE) values were greater than .5. Table 2 also shows that all composite reliability (CR) was greater than .7 and the square roots of AVE values were greater than inter-construct correlations, this, therefore, confirms the discriminant validity and convergent validity of the constructs used in this study (Fornell \& 
Table 3. Correlation

\begin{tabular}{|c|c|c|c|c|c|c|c|c|c|c|c|}
\hline Variables & $M$ & SD & $\mathrm{CR}$ & AVE & 1 & 2 & 3 & 4 & 5 & 6 & 7 \\
\hline 2. Age & 1.42 & .676 & & & $.693^{\star \star}$ & & & & & & \\
\hline 4. Perceived CSR & 4.01 & .410 & .926 & .648 & .003 & .004 & -.013 & .805 & & & \\
\hline 5. PA & 3.83 & .671 & .867 & .574 & -.102 & $-.134^{\star}$ & .001 & $.338^{\star \star}$ & .758 & & \\
\hline
\end{tabular}

Square roots of AVEs in bold in the diagonals. 
Larcker, 1981). Additionally, using AMOS, the study's data showed a good fit with the proposed four-factor model: $\chi^{2}[196]=545.3365, p<.001, \chi^{2} / d f=2.782, \mathrm{CFI}=.942$, IFI $=.942$, TLI $=.932$, SRMR $=.059$, RMSEA $=.074$ (Table 3 ).

To ensure that common method variance is not an issue in the current study, Harman's onefactor test and common latent factor test were employed. Although none of these tests are superior to the other, they make up for the limitation of each other (Podsakoff et al., 2003). All factors were loaded onto a principal components factor and it showed that no single factor accounted for a threshold of $50 \%$ variance. The first factor extracted accounted for $31.183 \%$ of the total variance extracted. The common latent factor test revealed that the difference in items' loading on the underlying latent construct is <.2, which is less than the .5 cut-offs (Eichhorn, 2014). Based on the results of these two techniques, there seems to be no substantial common factor bias.

\section{Hypothesis testing}

The study's hypotheses were tested using PROCESS macro (Hayes, 2018) with age, education level, and gender controlled for. Hypothesis 1 proposes that millennial joining intention is influenced by their perception of an organization's CSR. A bootstrap confidence interval with 5,000 resamples showed that perceived CSR predicts joining intention $(b=.1932 ; t=3.73 ; p<.01 ; 95 \%$ CI $[.1161, .3753])$. Hypothesis 2a postulates that the perception of CSR motive, i.e., an organization's PA will mediate the relationship between the organization's perceived CSR and joining intention. An indirect effect analysis revealed that PA mediates the relationship $(a b=.0444$, $\mathrm{SE}_{\mathrm{boot}}=.0194,95 \%$ CI $\left.[.0078, .0846]\right)$. Thus, Hypothesis $2 \mathrm{a}$ is supported. Hypothesis $2 \mathrm{~b}$, an indirect effect analysis also revealed that CSR-based OA mediates the relationship between an organization's perceived CSR and joining intention $\left(a b=.0923, \mathrm{SE}_{\mathrm{boot}}=.0263,95 \%\right.$ CI $\left.[.0468, .1503]\right)$. Thus, Hypothesis $2 \mathrm{~b}$ is also supported. Furthermore, CSR-based OA motive in Hypothesis $2 \mathrm{~b}$ has a slightly higher coefficient $(a b=.0923)$ than PA in Hypothesis $2 \mathrm{a}(a b=.0444)$ in the indirect relationship between perceived CSR and millennial joining intention. A further difference analysis check was conducted to assess the difference in coefficient effect size and the results were insignificant $\left(b=-.0479, \mathrm{SE}_{\mathrm{boot}}=.0357,95 \% \mathrm{CI}[-.1233, .0165]\right)$. That is, no statistically significant difference exists between the intervening mechanisms of CSR-based OA and PA when both mediation paths were compared in the model (Table 4).

\section{Conclusion and discussion}

This study aims to provide insight into the underlying relationship between perceived CSR and the joining intention of millennials through two CSR motive perceptions. Motive perception as purely altruistic, and out of genuine concern to stakeholders - PA; or as a means to boost organizational reputation, attractiveness, and also supply economic benefits to the firms - CSR-based $\mathrm{OA}$; are what plays a bigger role in millennial joining intention. Both mediators whose hypotheses are supported were selected based on stakeholders' evaluation of what motivates an organization's CSR practices. That is, millennials' disposition to pursue employment and join an organization is determined by their perception of the organization's CSR motivation.

Hypothesis 1 is supported and confirms that millennials are largely concerned about CSR. Similar to other millennials across the world that are often labeled as sensitive to ethical issues, and concerned with wanting to make a difference; Nigerian millennials are also disposed to, and have the intention of seeking employment opportunities with organizations that engage in CSR. This finding is not only consistent with that of previous studies conducted in the Western and Asian contexts (see Klimkiewicz \& Oltra, 2017; Waples \& Brachle, 2020), but it also provides a well-rounded theoretical perspective by expanding findings in prior CSR-HRM recruitment literature to include the African context. Generally, organizations that engage in CSR are likely to be considered as a good place to work, and millennials are predisposed to apply to these 
Table 4. Hypothesis testing

\begin{tabular}{|c|c|c|c|c|c|c|}
\hline & \multicolumn{2}{|c|}{ PA (model 1) } & \multicolumn{2}{|c|}{ CSR-based OA (model 2) } & \multicolumn{2}{|c|}{$\begin{array}{l}\text { Joining intention (model } \\
\text { 3) }\end{array}$} \\
\hline & $\beta$ & $\mathrm{Cl}(95 \%)$ & $\beta$ & $\mathrm{Cl}(95 \%)$ & $\beta$ & $\mathrm{Cl}(95 \%)$ \\
\hline Education level & -.103 & $\begin{array}{l}-.3591 \\
-.0018\end{array}$ & -.026 & $\begin{array}{r}-.1886 \\
.1142\end{array}$ & -.090 & $\begin{array}{r}-.2514 \\
.0066\end{array}$ \\
\hline Gender & -.001 & $-.1390, .1353$ & -.087 & $\begin{array}{r}-.2128 \\
.0197\end{array}$ & -.057 & $\begin{array}{r}-.1583 \\
.0394\end{array}$ \\
\hline PCSR & .338 & $.3868, .7203$ & .287 & $.2483, .5309$ & .193 & $.1161, .3753$ \\
\hline PA & & & & & .131 & $.0203, .1836$ \\
\hline CSR-based OA & & & & & .322 & $.2049, .3976$ \\
\hline $\mathrm{PCSR} \Rightarrow \mathrm{PA} \Rightarrow$ & & & & & .044 & $.0078, .0846$ \\
\hline $\begin{array}{l}\text { PCSR } \Rightarrow \text { CSR-based } \\
\text { OA }\end{array}$ & & & & & .092 & $.0468, .1503$ \\
\hline Total effect & & & & & .137 & $.0836,1999$ \\
\hline
\end{tabular}

Model 1 summary: $R=.3535, R^{2}=.1250, F(3,326)=15.52, p \leq .001$. Model 2 summary: $R=.3009, R^{2}=.0905, F(3,326)=10.82, p \leq .001$. Model 3 summary: $R=.5088, R^{2}=.2589, F(5,324)=22.64, p \leq .001$.

Total effect model: $R=.3575, R^{2}=.1278, F(3,326)=15.93, p \leq .001$.

organizations for employment. In addition to assessing the firm's ability to meet other expectations, millennials also review its ability to match their ethical and moral values. It can thus be argued that organizations' engagement in CSR is a strategic device, and a good signal to attract a large pool of millennial applicants during the recruitment stage. Although millennials may in the process consider the possible sense of identification, environmental/societal concern and value of being part of the potential employer's social image and reputation, the recruiting firm, would be able to select the most suitable candidates from a wide pool of applicants. Thus, to attract and recruit millennials, an organization must take a deliberate stance on CSR issues.

In hypothesis 2, empirical proof is provided for the direct effect of CSR on CSR motive perception of potential employees. It can be construed that potential millennial employees, similar to other widely studied stakeholder groups, also engage in some cognitive assessment through CSR-based OA and PA of an organization's societal/environmental commitment before seeking out, applying for, accepting or rejecting employment offers. This reasoning process is first shaped by stakeholders' environment as it provides the cues for evaluating and interpreting signals i.e., organization's CSR that are influential in predicting possible behavioral action such as joining intention (María \& Perez, 2018). Although potential employees may not be able to fully assess an organization's CSR dealings (Klimkiewicz \& Oltra, 2017) to arrive at an objective cognitive appraisal, millennials' evaluation could be dependable because of their deep concern for CSR issues and their wide access to information. Such an external opinion from millennials is important because it could be a pointer or a reflection of how the general public perceives an organization's CSR practices and the motivation behind them. It is this CSR motive perception that forms the basis for other reactions the organization may receive from the wider society it operates in, including millennial joining intention.

More specifically, hypotheses $2 \mathrm{a}$ and $2 \mathrm{~b}$ which state that PA and CSR-based OA independently mediate the indirect relationship between CSR and millennial joining intention are supported. Potential Nigerian millennial employees are willing to join an organization that engages in CSR if they perceive that CSR practices are performed: (1) altruistically with the moral intention of fulfilling obligations and doing good to society. As well as those (2), strategically conducted to 
gain stakeholders' attraction, and generate economic or reputational value for the organization. However, this is contrary to the findings in related studies such as Donia et al. (2019) and María and Perez (2018) that found only more altruistic CSR motives to positively affect stakeholder's behavioral intention toward an organization. Although PA has been identified more frequently over CSR-based OA to be a stronger CSR motive perception, potential millennial employees from Nigeria were inclined and attracted to pursue employment with organizations whose CSR motives are perceived as altruistic as well as those that enhance the organization's attractiveness.

The environment in developing countries presents a distinct and challenging set of CSR agendas (Alonso-Almeida \& Llach, 2019), which could shape millennial CSR motive perception and intention to join. For instance, CSR activities in developing nations take the form of resource contribution, socio-economic development, and other concerns pertaining the provision of basic education, capacity building, job creation, and social change which satisfy pressing societal needs, and compensate for the government's inadequacy (Uduji, Okolo-Obasi, \& Asongu, 2020). Consequently, everyone in the society directly or indirectly materially benefit from the CSR activities of an organization; whether the CSR motives are perceived as altruistic or solely to benefit the organization. Although Nigerian millennials consider the benefits that accrue to the general public as a result of perceived altruistic CSR motives, hypothesis $2 \mathrm{~b}$ also shows that organizational CSR not perceived as altruistic, but attributed to serving the interest of the organization is acceptable, and can influence joining intention.

In conclusion, although evidence demonstrates millennial job-seekers as generally interested in organizations that demonstrate good social standing, this study integrates some contributions that can be considered when explaining millennials' joining disposition toward CSR. It is vital to note that the contextual setting matters as this could engender different CSR motive perceptions about organizations' CSR and the eventual behavioral action of particular stakeholders. Although all millennials are concerned about issues of social responsibility, a cross contextual lesson can be drawn, in that response to CSR motive perceptions may differ. Therefore, organizations should pay cautious attention to factors in the environment that millennials are embedded in since it also performs a vital role in their CSR response and eventual decision to apply for job openings within an organization.

\section{Theoretical implication}

This study bears implication for the literature. The relationship among the study's variables has not been considered in extant studies, neither has any study considered potential millennial stakeholders, nor evaluated such model in a developing, and socio-economically uneven setting like many African countries. Other studies in the literature have focused on other national contexts but the environment in developing countries (e.g., Nigeria) is different and affects organizational CSR practices and how those practices are perceived (Ghosh, 2017). This difference necessitates a distinctive and separate focus on developing nations. This could be useful in shaping research and expanding the literature as influential insight about how perceptions about organizations' CSR motive may alter or undo the impact of CSR signal on stakeholders' outcome. By exploring CSR motive perceptions on joining intention of millennial job applicants, our finding recommends a new lens for examining CSR from the perspective of a millennial job applicant.

Some studies in the literature have used signaling theory to explain the relationship between CSR engagement, which are signals sent by organizations to particular stakeholders. Although information asymmetry may pose some limitations, stakeholders can decide to join the organization based on the information they have. This study extends this theoretical perspective by providing empirical proof to show that CSR signals to stakeholders but the process of deciding on the sent signal goes through the underlying cognitive process (CSR motive perception), which then 
motivates to seek employment with an organization. This also lends support to the recruitment literature in that applicants are still able to make a decision about potential employers even without having full information.

\section{Practical implication}

The increasingly competitive environment for recruiting talented employees and the benefits associated with attracting high-performing millennial employees underscore the need to understand influential factors. As our findings established, engaging in CSR is expected to provide organizations with such distinctness to win the battle for talent, sustain their competitiveness, and obtain other associated benefits. Practitioners must not underestimate job-seekers' CSR motive perception, as they are influential on individuals, especially millennials' assessment of an organization as a prospective workplace and on the overall decision of pursuing employment with that organization. They should attentively assess the underlying reason behind particular CSR choices, and implement CSR initiatives that are contextually relevant. Since the environment of operation not only primarily forms the bases by which CSR dealings and motives are cognitively evaluated, but guides behavioral responses.

Understanding this process and also considering the prevailing socio-economic context, the practitioners can gain insights required to not only frame effective CSR and recruitment systems and policies, but also achieve other associated benefits. This study also bears implications for the recruitment process and related decisions since CSR signals an organization's CSR orientation, ethical principles, and social values, such values are likely to differentiate an organization in the competitive market sphere. This can influence and promote subsequent attraction and engagement with the organization because CSR initiatives would thus align effectively with millennials' expectations and values. This would not only send favorable signals to millennials, but also enable organizations to implement appropriate CSR initiatives.

\section{Limitation and direction for further studies}

This study focused on the external dimension of CSR on potential job applicants in Nigeria and it may be challenging to extrapolate findings to countries with different characteristics. Nonetheless, it reflects that CSR motive perception affects disposition toward CSR. This points to research opportunities even among millennials in developed societies. Studies can consider other dimensions of CSR, the influence of other possible motives underlying organizational CSR engagement, and its outcome for other categories of employees. Considering that the survival of many organizations is hinged on ethical legitimacy, and the younger generation's demand for sustainable business practices and CSR, a comparative study that replicates this research can be performed to test our model across different contexts. It could also be worthwhile to further explore the reasons and context why CSR motive perceptions such as CSR-based OA and PA would not statistically differ. This can be analyzed against other outcomes such as motivation and retention and also among other stakeholder groups.

By establishing CSR-based OA and PA as the underlying mechanism, our study provides an understanding of the micro-level process by which organizational CSR influences prospective millennial employees. This unlocks other possibilities to explore more of such mechanism given that a better and more rounded understanding of the underlying mechanism can provide a strong foundation needed to design an effective CSR framework that not only provides support for novel CSR studies, but also long-term organizational policies including those for recruitment and staffing. The relationship can also be explored with potential employees who don't intend to pursue permanent employment with any organization but would prefer a freelancing job or being an entrepreneur. Additionally, other studies can consider examining the direct, indirect, or interacting impact of a company's size, profit, or cash flow on the relationship between CSR, CSR motive perception, and joining intention. This is because although firm size/financial capability 
is important for CSR, size or lack of resources should not be used as an excuse for not engaging in organizational CSR; especially in the case of developing nations where there are many small and medium organizations that have substantial impact on national and local economic development (Ogunmokun \& Timur, 2021; Stojanović et al., 2021).

\section{References}

Ahmad, T. (2019). Corporate social responsibility: A value-creation strategy to engage millennials. Strategic Direction, 35(7), 5-8. https://doi.org/10.1108/SD-11-2018-0232.

Akhouri, A., \& Chaudhary, R. (2019). Employee perspective on CSR: A review of the literature and research agenda. Journal of Global Responsibility, 10(4), 355-381. https://doi.org/10.1108/jgr-11-2018-0057.

Alonso-Almeida, M. D. M., \& Llach, J. (2019). Socially responsible companies: Are they the best workplace for millennials? A cross-national analysis. Corporate Social Responsibility and Environmental Management, 26(1), 238-247. https://doi.org/ $10.1002 /$ csr. 1675 .

Asante, B. E., He, Z., Bosompem, J., Opata, C. N., \& Boadi, E. K. (2020). Employees' perception of corporate social responsibility (CSR) and its effects on internal outcomes. Service Industries Journal, 40(9-10), 611-632. https://doi.org/10.1080/ 02642069.2019.1606906.

Carlini, J., Grace, D., France, C., \& Lo Iacono, J. (2019). The corporate social responsibility (CSR) employer brand process: Integrative review and comprehensive model. Journal of Marketing Management, 35(1-2), 182-205. https://doi.org/10. 1080/0267257X.2019.1569549.

Carlson, R. W., \& Zaki, J. (2018). Good deeds gone bad: Lay theories of altruism and selfishness. Journal of Experimental Social Psychology, 75, 36-40. https://doi.org/10.1016/j.jesp.2017.11.005.

Chaudhary, R. (2019). Green human resource management and job pursuit intention: Examining the underlying processes. Corporate Social Responsibility and Environmental Management, 26(4), 929-937. https://oi.org/10.1002/csr.1732.

Connelly, B. L., Certo, S. T., Ireland, R. D., \& Reutzel, C. R. (2011). Signaling theory: A review and assessment. Journal of Management, 37, 39-67. https://doi.org/10.1177/0149206310388419.

Conway, J. M., \& Lance, C. E. (2010). What reviewers should expect from authors regarding common method bias in organizational research. Journal of Business and Psychology, 25(3), 325-334. https://doi.org/10.1007/s10869-010-9181-6.

Donia, M. B. L., Ronen, S., Tetrault, S. C., \& Bonaccio, S. (2019). CSR by any other name? The differential impact of substantive and symbolic CSR attributions on employee outcomes. Journal of Business Ethics, 157(2), 503-523. https://doi.org/ 10.1007/s10551-017-3673-5.

Du, S., Bhattacharya, C. B., \& Sen, S. (2007). Reaping relational rewards from corporate social responsibility: The role of competitive positioning. International Journal of Research in Marketing, 24(3), 224-241. https://doi.org/10.1016/j.ijresmar. 2007.01.001.

Eichhorn, B. R. (2014). Common method variance techniques. Cleveland State University, Department of Operations \& Supply Chain Management, pp. 1-11. Retrieved from https://www.lexjansen.com/mwsug/2014/AA/MWSUG-2014AA11.pdf.

Fornell, C., \& Larcker, D. F. (1981). Structural equation models with unobservable variables and measurement error: Algebra and statistics. Journal of Marketing Research, 18(3), 382-388. https://doi.org/10.1177/002224378101800313.

Freeman, R. E. (2010). Strategic management: A stakeholder approach. Cambridge: Cambridge University Press. https://doi. org/10.1017/CBO9781139192675.

Ghosh, K. (2017). Corporate reputation, social performance, and organizational variability in an emerging country perspective. Journal of Management and Organization, 23(4), 545-565. https://oi.org/10.1017/jmo.2016.25.

Hair, J. F., Black, W. C., Babin, B. J., \& Anderson, R. E. (2010). Multivariate data analysis: A global perspective (7th ed). Boston: Englewood Cliffs: Prentice Hall.

Hayes, A. F. (2018). Partial, conditional, and moderated moderated mediation: Quantification, inference, and interpretation. Communication Monographs, 85(1), 4-40. https://doi.org/10.1080/03637751.2017.1352100.

Highhouse, S., Lievens, F., \& Sinar, E. F. (2003). Measuring attraction to organizations. Educational and Psychological Measurement, 63(6), 986-1001. https://doi.org/10.1177/0013164403258403.

Ikhide, J. E., Timur, A. T., Ogunmokun, O. A., \& Bayighomog, S. W. (2019). Employer value proposition and social responsibility in the age of social awareness: Joining intention of millenials cohort. In E. Kaynak \& T. Harcar (Eds.), International management development association - IMDA (pp. 262-263). England: Routledge.

Jiang, H., \& Luo, Y. (2020). Driving employee engagement through CSR communication and employee perceived motives: The role of CSR-related social Media engagement and job engagement. International Journal of Business Communication. https://doi.org/10.1177/2329488420960528.

Klimkiewicz, K., \& Oltra, V. (2017). Does CSR enhance employer attractiveness? The role of millennial job seekers' attitudes. Corporate Social Responsibility and Environmental Management, 24(5), 449-463. https://doi.org/10.1002/csr.1419. 
Kotek, K., Schoenberg, A. M., \& Schwand, C. (2018). CSR behavior: Between altruism and profit maximization. In Altenburger R (Ed.) , Innovation management and corporate social responsibility. CSR, sustainability, ethics \& governance (pp. 159-169). Cham, Switzerland: Springer. https://doi.org/10.1007/978-3-319-93629-1_8.

Kumari, S., \& Saini, G. K. (2018). Do instrumental and symbolic factors interact in influencing employer attractiveness and job pursuit intention? Career Development International, 23(4), 444-462. https://doi.org/10.1108/CDI-03-2018-0069.

Lievens, F., \& Slaughter, J. E. (2016). Employer image and employer branding: What we know and what we need to know. Annual Review of Organizational Psychology and Organizational Behavior, 3(1), 407-440. https://doi.org/10.1146/annurevorgpsych-041015-062501.

María, d. M. G.-D. 1. S., \& Perez, A. (2018). Effectiveness of CSR advertising: The role of reputation, consumer attributions, and emotions. Corporate Social Responsibility and Environmental Management, 25(2), 194-208. https://doi.org/10.1002/ csr.1453.

Nadler, J., Gann-Bociek, M., \& Skaggs, B. (2017). Interview support on perceptions of organizational attractiveness: The effects of applicant gender and socio-economic status. Management Research Review, 40(7), 783-799. https://doi.org/10. 1108/MRR-06-2016-0148.

Nishii, L. H., Lepak, D. P., \& Schneider, B. (2008). Employee attributions of the 'why' of HR practices: Their effects on employee attitudes and behaviors, and customer satisfaction. Personnel Psychology, 61(3), 503-545. https://doi.org/10. 1111/j.1744-6570.2008.00121.x.

Nolan, L. S. (2015). The roar of millennials: Retaining Top talent in the workplace. Journal of Leadership, Accountability and Ethics, 12(5), 69-75. Retrieved from http://t.www.na-businesspress.com/JLAE/NolanLS_Web12_5_.pdf.

Nunnally, J. C. (1978). Psychometric theory. New York: McGraw-Hill.

Nwagbara, U., \& Belal, A. (2019). Persuasive language of responsible organisation? A critical discourse analysis of corporate social responsibility (CSR) reports of Nigerian oil companies. Accounting, Auditing and Accountability Journal, 32(8), 2395-2420. https://doi.org/10.1108/AAAJ-03-2016-2485.

Ogunmokun, O., Eluwole, K. K., Ikhide, J. E., \& Lasisi, T. T. (2020). Dynamics of autonomy support leadership on Gen-Y employees in the Nigerian public service. Journal of Public Affairs, 1-12. https://doi.org/10.1002/pa.2571.

Ogunmokun, O., \& Timur, S. (2021). Customers' quality of life, advocacy and banks' CSR-fit: A cross-validated moderated mediation model. International Journal of Consumer Studies, 1-18. https://doi.org/10.1111/IJCS.12737.

Ogunmokun, O., Timur, S., Bayighomog, S. W., \& Ikhide, J. E. (2021a). Banks CSR-fit, customers' quality of life, and crossbuying: A joint moderation model. Psychology \& Marketing, 38(8), 1182-1196. https://doi.org/10.1002/MAR.21522.

Ogunmokun, O., Timur, S., \& Ikhide, J. E. (2021b). Reversing student attrition intensions using university COVID-19 response: A serial mediation and multi-group analysis. Journal of Marketing for Higher Education.

Onukwuba, H. (2020). Managing millennials in the African workplace: What the millennials need. Journal of Organizational Psychology, 20(2), 139-158. https://doi.org/10.33423/jop.v20i2.2884.

Ouyang, Z., Zhang, Y., \& Hu, X. (2020). Negative publicity and potential applicants' intention to apply amid a discrimination scandal: A moderated mediation model. Personnel Review, 50, 129-142. doi: https://doi.org/10.1108/PR-09-2019-0510.

Paraskevaidis, P., \& Andriotis, K. (2017). Altruism in tourism: Social exchange theory vs altruistic surplus phenomenon in host volunteering. Annals of Tourism Research, 62, 26-37. https://doi.org/10.1016/j.annals.2016.11.002.

Podsakoff, P. M., MacKenzie, S. B., Lee, J.-Y., \& Podsakoff, N. P. (2003). Common method biases in behavioral research: A critical review of the literature and recommended remedies. The Journal of Applied Psychology, 88(5), 879-903. https://doi.org/10.1037/0021-9010.88.5.879.

Raimi, L. (2018). Reinventing CSR in Nigeria: Understanding its meaning and theories for effective application in the industry. In Developments in corporate governance and responsibility (Vol. 13, pp. 143-176). Bingley: Emerald Publishing Limited. https://doi.org/10.1108/S2043-052320180000013012.

Ramasamy, S., Dara, S. K., Amran, A., \& Nejati, M. (2020). Linking human values to consumer CSR perception: The moderating role of consumer skepticism. Corporate Social Responsibility and Environmental Management, 27(4), $1958-1971$. https://doi.org/10.1002/csr.1939.

Rank, S., \& Contreras, F. (2021). Do millennials pay attention to corporate social responsibility in comparison to previous generations? Are they motivated to lead in times of transformation? A qualitative review of generations, CSR and work motivation. International Journal of Corporate Social Responsibility, 6(1), 1-13. https://doi.org/10.1186/s40991-02000058-y.

Rifon, N. J., Choi, S. M., Trimble, C. S., \& Li, H. (2004). Congruence effects in sponsorship: The mediating role of sponsor credibility and consumer attributions of sponsor motive. Journal of Advertising, 33(1), 30-42. https://doi.org/10.1080/ 00913367.2004.10639151.

Rim, H., Park, Y. E., \& Song, D. (2020). Watch out when expectancy is violated: An experiment of inconsistent CSR message cueing. Journal of Marketing Communications, 26(4), 343-361. https://doi.org/10.1080/13527266.2018.1523216.

Rim, H., Yang, S. U., \& Lee, J. (2016). Strategic partnerships with nonprofits in corporate social responsibility (CSR): The mediating role of perceived altruism and organizational identification. Journal of Business Research, 69(9), 3213-3219. https://doi.org/10.1016/j.jbusres.2016.02.035. 
Ronda, L., Valor, C., \& Abril, C. (2018). Are they willing to work for you? An employee-centric view to employer brand attractiveness. Journal of Product and Brand Management, 27, 573-596. https://doi.org/10.1108/JPBM-07-2017-1522.

Spence, M. (1978). Job market signaling. In Peter Diamond, \& Michael Rothschild (Eds.), Uncertainty in economics (pp. 281306). Cambridge, Massachusetts: Academic Press. https://doi.org/10.1016/B978-0-12-214850-7.50025-5.

Stojanović, A., Mihajlović, I., Safronova, N. B., Kunev, S., \& Schulte, P. (2021). The multi-criteria analysis of corporate social responsibility: A comparative study of Russia, Bulgaria and Serbia. Journal of Management and Organization, 1-21. https:// doi.org/10.1017/jmo.2020.40.

Tsai, W. C., \& Yang, I. W. F. (2010). Does image matter to different job applicants? The influences of corporate image and applicant individual differences on organizational attractiveness. International Journal of Selection and Assessment, 18(1), 48-63. https://doi.org/10.1111/j.1468-2389.2010.00488.x.

Turban, D. B., \& Keon, T. L. (1993). Organizational attractiveness: An interactionist perspective. Journal of Applied Psychology, 78(2), 184. Retrieved from https://psycnet.apa.org/record/1993-31597-001.

Turker, D. (2009). Measuring corporate social responsibility: A scale development study. Journal of Business Ethics, 85(4), 411-427. https://doi.org/10.1007/s10551-008-9780-6.

Turner, M. R., McIntosh, T., Reid, S. W., \& Buckley, M. R. (2019). Corporate implementation of socially controversial CSR initiatives: Implications for human resource management. Human Resource Management Review, 29(1), 125-136. https:// doi.org/10.1016/j.hrmr.2018.02.001.

Uduji, J. I., Okolo-Obasi, E. N., \& Asongu, S. A. (2020). Sustaining cultural tourism through higher female participation in Nigeria: The role of corporate social responsibility in oil host communities. International Journal of Tourism Research, 22 (1), 120-143. https://doi.org/10.1002/jtr.2323.

Vlachos, P. A., Panagopoulos, N. G., \& Rapp, A. A. (2013). Feeling good by doing good: Employee CSR-induced attributions, job satisfaction, and the role of charismatic leadership. Journal of Business Ethics, 118(3), 577-588. https://doi.org/10.1007/ s10551-012-1590-1.

Vuković, A., Miletić, L., Čurčić, R., \& Ničić, M. (2020). Consumers’ perception of CSR motives in a post-socialist society: The case of Serbia. Business Ethics, 29(3), 528-543. https://doi.org/10.1111/beer.12271.

Waples, C. J., \& Brachle, B. J. (2020). Recruiting millennials: Exploring the impact of CSR involvement and pay signaling on organizational attractiveness. Corporate Social Responsibility and Environmental Management, 27(2), 870-880. https://doi. org/10.1002/csr.1851.

Warmerdam, A., Lewis, I., \& Banks, T. (2015). Gen Y recruitment: Understanding graduate intentions to join an organisation using the theory of planned behaviour. Education and Training, 57(5), 560-574. https://doi.org/10.1108/ET-12-2013-0133.

Wongpitch, S., Minakan, N., Powpaka, S., \& Laohavichien, T. (2016). Effect of corporate social responsibility motives on purchase intention model: An extension. Kasetsart Journal of Social Sciences, 37(1), 30-37. https://doi.org/10.1016/j.kjss.2016. 01.010.

Cite this article: Ikhide JE, Tarik Timur A, Ogunmokun OA (2021). The strategic intersection of HR and CSR: CSR motive and millennial joining intention. Journal of Management \& Organization 1-19. https://doi.org/10.1017/jmo.2021.47 